This article has been published in:

Journal of Pragmatics 86 (2015) 5-10

Elsevier

http://dx.doi.org/10.1016/j.pragma.2015.05.010

If you want to quote from this document, please consult the page numbers in the right hand margins.

\title{
Interpersonal pragmatics and its link to (im)politeness research
}

\author{
Miriam A. Locher
}

\begin{abstract}
In light of the fact that politeness research has been on the map since the 1970s, this paper revisits some of the more recent developments. The scope of analysis has been widened from face-maintaining and face-enhancing data to instances of conflictual and faceaggravating behaviour. There is an increase in discussions about appropriate methodological and theoretical approaches to politeness, and we see a tendency to creatively draw on approaches from other fields (such as identity construction research). These trends have made the field an especially vibrant one that is currently witnessing a struggle to (re)define its focus. Two connected issues (clarifying and refining the scope of our research questions and efforts of developing an interdisciplinary approach within interpersonal pragmatics) are particularly discussed in an endeavour to outline potential research paths.
\end{abstract}

Keywords: Relational work; Interpersonal pragmatics; Pragmatic turn; Discursive turn; (Im)politeness; Methodology

\section{Introduction}

Research on politeness has been a set topic within pragmatics ever since Lakoff (1973), Brown and Levinson (1978/1987) and Leech (1983; see also 2014), as the most influential early scholars, put the topic firmly on the linguistic agenda. In an endeavour to explain pragmatic variation in naturally-occurring data on the one hand (as part of the 
pragmatic turn) and still working within a mind set that proposed 'rules' and universals on the other, their thinking has influenced all following scholars within this field of interest. Roughly from the 1990s onwards, however, the scope of analysis has been widened from face-maintaining and face-enhancing data to instances of conflictual and face-aggravating behaviour. We have also witnessed an increase in discussions about appropriate methodological and theoretical approaches to politeness and a tendency to creatively draw on approaches from other fields (such as identity construction research). These trends have made the field an especially vibrant one that is currently witnessing a struggle to (re)define its focus. Culpeper's work on his own and with colleagues has shaped these discussions considerably since he was among the first to broaden the scope of interest to include impoliteness phenomena (e.g. 1996, 2005, 2010, 2011; Culpeper et al., 2003; Bousfield \& Culpeper, 2008), to also work with fictional and historical data (e.g. 1996, 1998, 2010; Culpeper \& Kádár, 2010; Culpeper \& Demmen, 2011) and to ceaselessly question and discuss current wisdom within the research community (e.g. 2012; Culpeper \& Haugh, 2014; or the current extensive project on the Palgrave Handbook of Linguistic (Im)Politeness, Culpeper, Haugh \& Kádár). In what follows, I want to offer some thoughts on two connected issues that are currently being discussed and that bear further thinking: the scope of our research questions and efforts of developing an interdisciplinary approach within interpersonal pragmatics.

Although the early theories by Lakoff, Leech and Brown and Levinson are still very much used today, one of the achievements of what has been termed the 'discursive approaches to politeness research' was to again draw attention to the negotiability of the emic understandings of evaluative concepts such 'polite', 'impolite', 'rude', etc., and, in connection with this, to highlight the embeddedness of the observed social practices within their local situated framework of the moral order (see, e.g., Kádár and Haugh 2013, p. 95). It is of course true that all of the early theories at one stage or another allow for variability in understanding. This insight faded into the background once scholars started to apply the suggested 'rules' by rote. The discursive approaches try to allow for the fact that there are societal ideologies of politeness and impoliteness, while at the same time acknowledging that the practices we are studying may deviate from these more general norms. Culpeper $(2008$, p. 30) tried to pinpoint this by introducing the idea of personal, cultural, situational and co-textual norms that shape interaction. Kádár and Haugh (2013, p. 95) speak of (1) localised norms, (2) "community of practice/organisational or other group-based norms," and societal/cultural norms as shaping the moral order that underpin all evaluations of politeness.

Some of the critics of the discursive approaches say that focusing on the interactants' own understanding of (im)politeness ultimately leads to abandoning the study of 
(im)politeness. ${ }^{1}$ For example, recently, Haugh (2013), who is also an advocate of the discursive approaches, used an interesting formulation in this connection. He deplores that Locher and Watts $(2005,2008)$ "are forced to retreat to only making claims that something is 'open to evaluation' as polite, impolite and so on" (italics added) and asks "[h]ow do we as analysts confidently identify instances of im/politeness?" (Haugh, 2013, p. 55). We have indeed used such phrases when describing interaction in situ, but do not consider this a defeat. Rather, it is an attempt to pay tribute to the qualitative nature of the analysis and the discursive nature of the concept. We are not 'forced' to give up, but phrasings such as 'behaviour is open to evaluation as polite' are the consequence of our theoretical position. We aim at offering a qualitative interpretation based on linguistic and non-linguistic cues that reveal the interpersonal stance that the interactants take towards each other and towards (im)politeness norms. This position is based on the belief that societal norms are in flux and negotiated in interaction (while acknowledging the importance of frames with their cognitive and historical nature). As outlined above, more widely shared beliefs can be co-present with local norms of a community of practice. Since we understand politeness as a judgement by interactants on one's own and other's behaviour that is grounded in a particular society's beliefs and value system and its variants in local communities of practice, its surface forms will also be in flux (see also Kádár and Haugh, 2013, p. 69, on the idea of politeness as social practice). This has been shown in cultural differences in the understanding of what constitutes politeness or the mere fact that the concept has its own historicity and different connotations in different languages. From this perspective, it is not the primary aim to pinpoint particular instances of linguistic surface forms to be able to say that these are instances of undeniable polite (or impolite) behaviour. Instead, such research reveals the negotiation of relational meaning and the struggle over ideologies of adequate behaviour.

It is worthwhile to keep in mind that scholars differ in their research agendas. The early theories used the term 'politeness' as a shorthand to describe much more fundamental processes of meaning making. The question raised by Haugh above is thus narrower in scope than the ones raised in the early theories of politeness, which, inspired by and contributing to the pragmatic turn, wanted to address pragmatic variation in general. Lakoff suggested her three rules of politeness in connection with Grice's CP and analogous to syntactic rules of language use. Leech proposed his Politeness Principle as one of the pillars of his theoretical framework 'Interpersonal Rhetoric', which aimed at explaining how people create meaning, i.e. not just the creation of politeness. In Brown and Levinson's approach, we see the introduction of the concept of 'face' and psychological wants of involvement and distancing. All approaches highlight constraints on interaction (e.g. closeness and distance, power differences, the ranking of the imposition within its cultural context) and thus contribute to theorising how relationships are indexed through linguistic choices and how such linguistic cues will lead to certain interpersonal interpretations. In this spirit of the broader approach to studying sociality and (linguistic)

\footnotetext{
${ }^{1}$ For arguments against this view, see Locher (2012, pp. 51-53).
} 
relationship construction, scholars have worked with concepts such as facework, rapport management or relational work. To describe this field of research, Graham and I speak of 'Interpersonal Pragmatics,' by which we mean a relational/ interpersonal perspective on studying interaction (Locher and Graham, 2010, p. 2; see also Haugh et al., 2013, p. 9), no matter which concepts you use for analysis. Adopting an interpersonal perspective does not mean that one has to exclusively focus on (im)politeness concerns, but it may well be a focus.

In recent years, scholars have adopted a number of theoretical concepts and positions in order to discuss data with an interpersonal lens (some more, some less compatible with each other, and all going beyond the classical politeness approaches). Arundale (2010a,b), for example, develops a face-constituting theory, that, as he clearly states, is not synonymous with politeness theory. Langlotz $(2010,2015)$ develops a socio-cognitive theory of situated social meaning. Locher and Watts $(2005,2008)$ suggest adopting the concept of frame with its historical and cognitive dimension and adaptability to situate discussions of data in their local and social context. Garcés-Conejos Blitvich (2013), in contrast, proposes using Fairclough's notions of discourse, genre and style in order to study the dynamic development of norms. Spencer-Oatey $(2007,2011)$, Locher (2008, 2012, 2014) and Garcés-Conejos Blitvich (2009) point out that there is a close connection between identity construction and the politeness concerns previously discussed in the (im)politeness literature. Locher and Langlotz (2008; Langlotz \& Locher, 2012, 2013, forthcoming), Spencer-Oatey (2011), Culpeper (2011), Culpeper et al. (2014), and Kádár and Haugh (2013) point to the crucial role that emotions play in negotiating meaning and relationships and thus also draw on insights from cognition and psychology. Culpeper and Haugh (2014, pp. 197-198) argue that studying interpersonal attitudes (including interpersonal emotions and interpersonal evaluations) deserves more attention. Culpeper (2011), Kádár and Haugh (2013) and Haugh (2015) explore the usefulness of studying metapragmatic markers and Haugh (2015) zooms in on (im)politeness implicatures.

What is evident in this incomplete and patchy overview is that (im)politeness scholars are quite happy - as they should be - to draw creatively on concepts from other research strands in an endeavour to sharpen our analytical tools for what is happening at the interpersonal level of data. However, the role that '(im)politeness' plays within these approaches differs quite substantially. For some, an (im)politeness norm is one of many potential explanatory avenues to explain a stretch of interaction or an instance of meaning-making. For others, (im)politeness constitutes the main social constraint in their theoretical reasoning of explaining variation. It follows that it is always worthwhile to carefully establish what the scholars are aiming at achieving with their particular research design.

\section{Mixing methodologies and drawing on other linguistic and interdisciplinary research fields}

The second issue worth noting is that (im)politeness scholars clearly see a need to 
move beyond the original theories and to combine them with other research strands from linguistics (e.g. work on identity construction) and other non-linguistic disciplines. This is visible in how scholars are now mixing linguistic methodologies so that we are confronted with a wide gamut of data types (from invented examples, experimental data derived from DCTs and role plays, to naturally-occurring face-to-face and written data, corpora, fieldwork, and interviews with participants) and methodological tools. Furthermore, linguistic theories are enriched with insights from other disciplines. For example, Culpeper's (2011) book on (im)politeness highlights the fundamentally interdisciplinary nature of impoliteness phenomena by drawing on insights from social psychology, sociology, conflict studies, media studies, business studies, history, literary studies, etc. If we were to add the more consent-oriented politeness side of the spectrum of relational work, the fields of rhetoric and persuasion studies (in the sense of creating alignment and disalignment) come also to mind.

At the same time, it is of interest that scholars working with the theories that are being drawn on do not always see the same necessity to incorporate insights from the (im)politeness literature into their thinking. For example, scholars working within a conversation analysis framework often speak of observing how interactants are 'doing delicacy' (e.g. Silverman and Peräkylä, 1990; Miller, 2013), without having to draw on the concepts of (im)politeness for their explanations. In their epilogue to the special issue on face, identity and (im)politeness in the Journal of Politeness Research, Hall and Bucholtz (2013) acknowledge the potential advantage in drawing more on the concept of 'face' and 'facework' in their own explorations, but do not mention the same need to develop a politeness framework in order to satisfactorily elaborate on identity construction:

We have titled this epilogue "Facing identity" as a bidirectional call for a deeper consideration of the relationship between face and identity: to scholars of politeness to consider the place of identity in facework; and to scholars of identity to consider the place of face in identity work. Although we did not explicitly build politeness into our model of identity and interaction, we are now freshly reminded, after familiarizing ourselves with the excellent research featured in this special issue, that facework, at once rational and emotional, is fundamental to the workings of identity, as human positioning is always sensitive to the reflection of one's image in the eyes of another. (Hall and Bucholtz, 2013, p. 130)

A similar stance can be observed in many of the studies in applied linguistics. When recently preparing the literature review for a chapter on (im)politeness in health settings (Locher and Schnurr, forthcoming), it was striking to what extent there is an abundance of literature that discusses phenomena relevant to our field (doing delicacy, attending to the taboo nature of a health topic, negotiating differences in knowledge and power, using lexical hedges and humour for mitigation, etc.). The vast majority of these studies, however, did not (have to) draw on insights from (im)politeness research to validly describe interaction for their purposes. This ultimately raises the question of the nature of the early theories and

also of our current thinking. For example, if the creation of meaning in interaction can be explained without drawing on the politeness principle (Leech) or the notion of mitigation 
and the nature of a face-threatening act (Brown and Levinson), what does this mean with respect to the assumed universal nature of the constraints that these theories propose? How are the observed strategies to be understood in relation to whatever else is going on? What is the relation of (im)politeness theories to other theories developed in historical linguistics, the study of identity construction, but also rhetoric and persuasion, cognitive linguistics and applied linguistics?

There are no easy answers to these questions. In my own work within Interpersonal Pragmatics, I have tried to free myself from what I have come to perceive as a somewhat restrictive theoretical label (i.e. 'politeness' as a theoretical concept without its emic connotations), that is no longer adequate for what I want to explore (practices and their relational component more holistically). This has led me to adopt a more open perspective on relational work (i.e. the concept "refers to all aspects of the work invested by individuals in the construction, maintenance, reproduction and transformation of interpersonal relationships among those engaged in social practice," Locher and Watts, 2008 , p. 96), which allows me to still work with the concept of face by describing facemaintaining, face-enhancing or face- aggravating multi-modal strategies of relationship negotiations. This means that I wholeheartedly endorse Hall and Bucholtz's (2013, p. 130) call quoted above to combine the study of relational work with identity construction. In addition, what is happening at the relational level of communication is not the only aspect important for communication. This is, of course, no new insight; however, it bears reminding ourselves that theories should not simply be applied without a holistic analysis of the data extracts we are analysing. In work currently conducted in the context of a project on language and health online, we thus try to combine content analysis (with the help of discursive moves) with an analysis of relational work strategies. ${ }^{2}$ What we observe are subtle negotiations of positionings of the interactants vis-à-vis each other at crucial moments within the composition of the texts that result in relationship negotiation in addition to whatever else is going on (such as information exchange, counselling, adviceseeking and -giving, etc.). Nevertheless, while my research interest has thus moved away from an exclusive focus on politeness, it is still possible to discuss instances of interaction where the emic notion becomes relevant. To acknowledge that 'politeness' in this framework is a clearly evaluative and situated concept that is part of the moral order as outlined above will then let the analyst point to instances where such meaning is negotiated. This, in turn, will allow us to understand the underlying politeness ideologies better, but may also reveal how they overlap, reinforce or contradict other ideologies that shape sociality (e.g., ideologies on gender, class, age, professionalism, etc.).

Another research path is to give full attention to a particular aspect within relational work (such as impoliteness or politeness) rather than to a particular practice (e.g. advicegiving in a health context, email requests by students, etc.). In his work on impoliteness,

\footnotetext{
2 The methodology builds on Locher (2006), in which I looked at an online advice column in English. The data we are currently working on is an in-depth study of a number of email counselling cases from a UK university and computer-mediated communication in the form of peer advice sites and professional health sites on smoking cessation (https://language-health-online.unibas.ch/).
} 
Culpeper (2011, p. 3) does just that since he combines different data and methods (fieldnotes, interviews, questionnaires, corpus data, etc.) in an attempt to work on as many instantiations and meta-discussions of the phenomenon as possible. He also particularly stresses the interdisciplinary nature of impoliteness phenomena by drawing on insights from the disciplines listed above. This is clearly one way to go as it gives justice to the themes (i.e. impoliteness and politeness phenomena) that are more than mere linguistic surface structures and deserve to be studied in their historical, social, and local context (in different cultural and linguistic settings). Approaching the chosen topics from as many different angles as possible is thus a worthy tradition that should be continued.

\section{Concluding comments}

Ultimately, what I claim in this brief contribution in honour of Culpeper's outstanding work in the field of (im)politeness studies is not that any of the outlined and hinted at directions are better than the next but that different approaches may well be combined in analysis. We should, however, not lose sight of the (sometimes subtle) differences in research questions that are being asked and for which methodological tools are being sharpened within interpersonal pragmatics. The scope of our aims differs quite considerably from attempting to establish universals in linguistic interaction and sociality on the one hand to detailed analysis of relational cues in particular quite local practices. Depending on their research questions, scholars can creatively combine methodological tools and (interdisciplinary) theoretical insights in pursing their specific research endeavours and build on each other's findings, no matter whether they define their research goal as understanding a particular practice with all its facets or exploring personal, cultural, situational and co-textual norms and ideologies that shape interaction more globally.

References

Arundale, R.B., 2010a. Constituting face in conversation: face, facework, and interactional achievement. J. Pragmat. 42 (8), 2078-2105. http://dx.doi.org/10.1016/j.pragma.2009.12.021 Arundale, R.B., 2010b. Relating. In: Locher, M.A., Graham, S.L. (Eds.), Interpersonal Pragmatics. Mouton de Gruyter, Berlin, Germany, pp. 137-167.

Bousfield, D., Culpeper, J., 2008. Impoliteness: eclecticism and diaspora. An introduction to the special edition. J. Politeness Res. 4 (2), 161-168. http://dx.doi.org/10.1515/JPLR.2008.008 Brown, P., Levinson, S.C., 1987. Politeness. Some universals in language usage Cambridge University Press, Cambridge, England (original work published 1978).

Culpeper, J., 1996. Towards an anatomy of impoliteness. J. Pragmat. 25 (3), 349-367. http://dx.doi.org/10.1016/0378-2166(95)00014-3

Culpeper, J., 1998. (Im)politeness in drama. In: Verdonk, P., Short, M., Culpeper, J. (Eds.), Exploring the Language of Drama: From Text to Context. Routledge, London, England, pp. 83-95. 
Culpeper, J., 2005. Impoliteness and entertainment in the television quiz show: The Weakest Link. J. Politeness Res. 1 (1), 35-72. http://dx.doi. org/10.1515/jplr.2005.1.1.35

Culpeper, J., 2008. Reflections on impoliteness, relation work and power. In: Bousfield, D., Locher, M.A. (Eds.), Impoliteness in Language. Studies on its Interplay with Power in Theory and Practice. Mouton de Gruyter, Berlin, Germany, pp. 17-44.

Culpeper, J., 2010. Conventionalised impoliteness formulae. J. Pragmat. 42 (12), 3232-3245. http://dx.doi.org/10.1016/j.pragma. 2010.05.007

Culpeper, J., 2011. Impoliteness. Using Language to Cause Offence. Cambridge University Press, Cambridge, England.

Culpeper, J., 2012. Epilogue: (im)politeness: three issues. J. Pragmat. 44 (9), 1128-1133. http://dx.doi.org/10.1016/j.pragma.2012.05.011

Culpeper, J., Demmen, J., 2011. Nineteenth-century English politeness: negative politeness, conventional indirect requests and the rise of the individual self. J. Hist. Pragmat. 12 (1-2), 49-81. http://dx.doi.org/10.1075/jhp.12.1-2.03cul

Culpeper, J., Haugh, M., 2014. Pragmatics and the English Language. Palgrave Macmillan, Houndmills, England.

Culpeper, J., Kádár, D.Z. (Eds.), 2010. Historical (Im)politeness. Peter Lang, Bern, Switzerland.

Culpeper, J., Bousfield, D., Wichmann, A., 2003. Impoliteness revisited: with special reference to dynamic and prosodic aspects. J. Pragmat. 35 (10--11), 1545-1579. http://dx.doi.org/10.1016/S0378-2166(02)00118-2

Culpeper, J., Schauer, G., Marti, L., Mei, M., Nevala, M., 2014. Impoliteness and emotions in a cross-cultural perspective. In: Langlotz, A., Soltysik Monnet, A. (Eds.), Emotion, Affect, Sentiment: The Language and Aesthetics of Feeling. Narr, Tübingen, Germany, pp. 67-88.

Culpeper, J., Haugh, M., Kádár, D.Z. (Eds.). Palgrave Handbook of Linguistic (Im)politeness. Palgrave Macmillan, London, England (forthcoming).

Garcés-Conejos Blitvich, P., 2009. Impoliteness and identity in the American news media: the "Culture Wars". J. Politeness Res. 5 (2), 273-303. http://dx.doi.org/10.1515/JPLR.2009.014

Garcés-Conejos Blitvich, P., 2013. Introduction: face, identity and im/politeness. Looking backward, moving forward: from Goffman to practice theory. J. Politeness Res. 9 (1), 1-33. http://dx.doi.org/10.1515/pr-2013-0001

Hall, K., Bucholtz, M., 2013. Epilogue: facing identity. J. Politeness Res. 9 (1), 123-132. http://dx.doi.org/10.1515/pr-2013-0006

Haugh, M., 2013. Im/politeness, social practice and the participation order. J. Pragmat. 58, 52-72. http://dx.doi.org/10.1016/j. pragma.2013.07.003

Haugh, M., 2015. Im/politeness Implicatures. Mouton de Gruyter, Berlin, Germany.

Haugh, M., Kádár, D.Z., Mills, S., 2013. Interpersonal pragmatics: issues and debates. J. Pragmat. 58, 1-11. http://dx.doi.org/10.1016/j. pragma.2013.09.009

Kádár, D.Z., Haugh, M., 2013. Understanding Politeness. Cambridge University Press, Cambridge, England.

Lakoff, R.T., 1973. The logic of politeness, or minding your p's and q's. Chic. Linguist. Soc. 9, 292-305.

Langlotz, A., 2010. Social cognition. In: Locher, M.A., Graham, S.L. (Eds.), Interpersonal Pragmatics. Mouton de Gruyter, Berlin, Germany, pp. 167-202.

Langlotz, A., 2015. Creating Social Orientation Through Language: A Socio-cognitive Theory of Situated Social Meaning. John Benjamins, Amsterdam, Netherlands. 
Langlotz, A., Locher, M.A., 2012. Ways of communicating emotional stance in online disagreements. J. Pragmat. 44 (12), 1591-1606. http://dx.doi.org/10.1016/ j.pragma.2012.04.002

Langlotz, A., Locher, M.A., 2013. The role of emotions in relational work. J. Pragmat. 58, 87-107. http://dx.doi.org/10.1016/j.pragma.2013.05.014

Langlotz, A., Locher, M.A. (Im)politeness and emotion. In: Culpeper, J., Haugh, M., Kádár, D.Z. (Eds.), Palgrave Handbook of Linguistic (Im) politeness. Palgrave Macmillan, London, England (forthcoming).

Leech, G.N., 1983. Principles of Pragmatics. Longman, New York, NY. Leech, G.N., 2014. The Pragmatics of Politeness. Oxford University Press, Oxford, England.

Leech, G.N., 2014. The Pragmatics of Politeness. Oxford University Press, Oxford, England. Locher, M.A., 2006. Advice Online. Advice-giving in an American Internet Health Column. John Benjamins, Amsterdam.

Locher, M.A., 2008. Relational work, politeness and identity construction. In: Antos, G., Ventola, E., Weber, T. (Eds.), Handbooks of Applied Linguistics. Volume 2: Interpersonal Communication. Mouton de Gruyter, Berlin, Germany, pp. 509-540.

Locher, M.A., 2012. Politeness research from past to future, with a special focus on the discursive approach. In: Fernández Amaya, L., Hernández López, M., Gómez Morón, R., Padilla Cruz, M., Mejías Borrero, M., Relinque Barranca, M. (Eds.), New Perspectives on (Im)politeness and Interpersonal Communication. Cambridge Scholars, Cambridge, England, pp. 36-60.

Locher, M.A., 2014. The relational aspect of language: avenues of research. In: Mergenthal, S., Nischik, R.M. (Eds.), Anglistentag 2013 Konstanz: Proceedings. Wissenschaftlicher Verlag Trier, Trier, Germany, pp. 309-322.

Locher, M.A., Graham, S.L., 2010. Introduction to interpersonal pragmatics. In: Locher, M.A., Graham, S.L. (Eds.), Interpersonal Pragmatics. Mouton de Gruyter, Berlin, Germany, pp. 1-13. Locher, M.A., Langlotz, A., 2008. Relational work: at the intersection of cognition, interaction and emotion. Bulletin Suisse de Linguistique Appliquée (VALS-ASLA) 88, 165-191 retrieved from http://doc.rero.ch/record/11876/files/bulletin_vals_asla_2008_088.pdf

Locher, M.A., Schnurr, S. (Im)politeness in health contexts. In: Culpeper, J., Haugh, M., Kádár, D.Z. 10 (Eds.), Palgrave Handbook of Linguistic (Im)politeness. Palgrave Macmillan, London, England $\downarrow$ (forthcoming).

Locher, M.A., Watts, R.J., 2005. Politeness theory and relational work. J. Politeness Res. 1 (1), 933. http://dx.doi.org/10.1515/jplr.2005.1.1.9

Locher, M.A., Watts, R.J., 2008. Relational work and impoliteness: negotiating norms of linguistic behaviour. In: Bousfield, D., Locher, M.A. (Eds.), Impoliteness in Language. Studies on its Interplay with Power in Theory and Practice. Mouton de Gruyter, Berlin, Germany, pp. 77-99.

Miller, E.R., 2013. Positioning selves, doing relational work and constructing identities in interview talk. J. Politeness Res. 9 (1), 75-95. http://dx.doi.org/10.1515/pr-2013-0004

Silverman, D., Peräkylä, A., 1990. AIDS counseling: the interactional organization of talk about 'delicate' issues. Soc. Health IIIn. 12 (3), 293-318. http://dx.doi.org/10.1111/14679566.ep11347251

Spencer-Oatey, H., 2007. Theories of identity and the analysis of face. J. Pragmat. 39 (4), 639-656. http://dx.doi.org/10.1016/j.pragma.2006.12.004 
Spencer-Oatey, H., 2011. Conceptualising 'the relational' in pragmatics: insights from metapragmatic emotion and (im)politeness comments. J. Pragmat. 43 (14), 3565-3578. http://dx.doi.org/10.1016/j.pragma.2011.08.009

Miriam A. Locher is Professor of the Linguistics of English at the University of Basel, Switzerland. She works in the field of politeness and relational work research (Power and Politeness in Action, 2004; Impoliteness in Language, 2008, ed. with D. Bousfield), and advice-giving (Advice Online, 2006; Advice in Discourse, 2012, ed. with Holger Limberg). She further edited collections on Standards and Norms of the English language (2008, with J. Strässler), on CMC and politeness/relational work (Journal of Politeness Research and Pragmatics), Narrative Matters in Medical Contexts across Disciplines (2015, with F. Gygax) and edited the handbook of Interpersonal Pragmatics (2010, with S. Graham). She is currently working on an SNF project on Language and Health Online, linguistic identity construction in Facebook with B. Bolander, and on the connection between emotional display and relational work with A. Langlotz. 